\title{
The Effect of Green Label, Perceived Quality, and Brand Image on Purchase Intention of Tissue Plenty in Jakarta
}

\author{
Nofilia Faulina Perlambang ${ }^{1 *}$ Eko Harry Susanto ${ }^{2}$
}

\author{
${ }^{1}$ Master of Management Program, Universitas Tarumanagara, West Jakarta 11440, Indonesia \\ ${ }^{2}$ Faculty of Communication Science, Universitas Tarumanagara, West Jakarta 11440, Indonesia. \\ ${ }^{*}$ Corresponding author. Email: nperlambang@yahoo.com
}

\begin{abstract}
The development of the paper industry has decreased as a result of widespread issues of climate change, global warming, deforestation, narrowing forest land and the transfer of paper use to digital. On the other hand, companies are required to continue producing in order to survive, develop and generate profits. One of the products made from paper raw materials that has experienced an increase in demand from year to year is tissue. In China, in order to boost the tourism sector, the government is campaigning for cleanliness, making the demand for tissue increasing. In Indonesia, one of the tissue products that supports the tourism sector by supplying tissue to hotels, restaurants and malls is Plenty. However, in the Indonesian paper industry, Plenty has to compete with other brands. One of its main competitors is Passeo which is owned by Sinarmas. This study aims to determine how far the relationship between green label, perceived quality and brand image affects purchase intention in Plenty's products in Jakarta. Data obtained from questionnaires distributed via Google Form. The sample used in this study were 119 respondents. with the help of IBM SPSS Version 21, the result is green label, perceived quality and brand image have a positive effect on purchase intention.
\end{abstract}

\section{Keywords: Green Label, Perceived Quality and Brand Image and Purchase Intention}

\section{INTRODUCTION}

The development of the paper industry has decreased as a result of widespread issues of climate change, global warming, deforestation, narrowing forest land and the transfer of paper use to digital. According to data from Global Forrest Watch, the loss of primary forest in Indonesia reached more than 6.02 million ha from 2000 to 2012 and increased by an average of 47,600 ha per year [1]. But on the other hand, companies are required to continue to innovate, adapt and produce in order to survive, develop and generate profits in the industry. Along with the times, tissue is a familiar object in everyday life, almost every day humans use tissue. Tissue itself now has many variants ranging from wet tissue, rolled tissue, eating tissue, and so on. The human lifestyle that wants to be instantaneous has made tissue become a very familiar thing lately. It was different during the 70s, where rags or handkerchiefs were still things that had to be carried when traveling.

According to data obtained from the Ministry of Industry 2017, the development of the tissue industry in Indonesia has grown from year to year. This is because tissue is a product with a high level of consumption in household life. The practicality in cleanliness offered when consumers use tissue is the main motive for consumers to purchase this product. The phenomenon of big city people provides opportunities for tissue-making producers to market their products to consumers.

Referring to the data above, it is a reason for researchers to find out what factors influence the interest in buying Plenty products. The title in this study is "The Effect of Green Label, Perceived Quality and Brand Image on Purchase Intention of Plenty Products in Jakarta".

\section{RESEARCH OBJECTIVES}

The purpose of this study was to determine the effect of environmentally friendly strategies, perceived quality and brand image on buying interest in tissue Plenty products in Jakarta. In addition to this, to find out the factors that have a dominant influence on buying interest in Plenty's tissue in Jakarta. Based on the description above, the hypothesis in this study can be formulated as follows:

$\mathrm{H}_{1}$ : Green label has a positive effect on purchase intention of Plenty's products in Jakarta

$\mathrm{H}_{2}$ : Perceived quality has a positive effect on purchase intention of Plenty's products in Jakarta

$\mathrm{H}_{3}$ : Brand image has a positive effect on purchase intention of Plenty products in Jakarta 


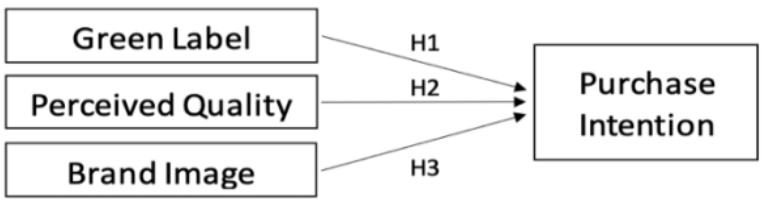

Figure 1 Research Model

\section{LITERATURE REVIEW}

\subsection{Green Label}

According to Chen, green marketing activities are activities that involve the company's efforts in developing, differentiating, innovating and promoting products to meet customer needs and preferences without causing environmental damage [2].

\subsection{Perceived Quality}

According to (Wheelock \& Wilson, 1995), perceived quality is the relative value of the product and customer expectations of the product. This means when a customer buys a certain product, they buy the expectation of the product [3].

\subsection{Brand Image}

According to (Magnusson \& Cranfield, 2003), product image is a consumer's perception of certain brand attributes (whether the brand is innovative, stylish or fashionable) and is an important component of brand equity [4].

\subsection{Purchase Intention}

Purchase intention is a desire that arises in consumers for a product as a result of the consumer's observation and learning process on a product.

\section{RESEARCH METHODOLOGY}

The population in this study are people who have heard of Plenty's products in the Jakarta area. The sample selection was carried out using a non-probability sampling method. The non-probability sampling technique chosen was purposive sampling.

Based on the references (Hair \& Joseph, 2006), the sample size should be between 30 and 500 respondents. With this reference, the researcher decided the number of samples used in this study was 187 respondents. To test the validity and reliability analysis, data analysis and data analysis assumptions used the Statistical Package for the Social Sciences (SPSS) software version 21 [5].

The study used a questionnaire that was distributed online, using the google form which was distributed on 10 October - 20 October 2020. Filtering questions were used to filter data from respondents to make it suitable for the study. Namely, never heard of Plenty tissue products. And the data that can be used in this study are 119 samples, because 68 respondents have never heard of Plenty's tissue products. Hypothesis testing in this study uses multiple linear regression. Multiple linear regression is intended to determine the linear relationship between several independent variables which are commonly referred to as $\mathrm{X} 1, \mathrm{X} 2, \mathrm{X} 3$, and so on with the dependent variable called $\mathrm{Y}$ [6].

\section{RESULTS AND CONCLUSIONS}

The results of this study indicate that testing the validity and reliability as well as testing the classical assumptions of the regression model is free from the problems of normality, multicollinearity and heteroscedasticity. Thus the regression model is appropriate to use in testing the hypothesis in this study.

Table 1 t-Test

Coefficients

\begin{tabular}{|c|c|c|c|c|c|c|c|c|}
\hline \multirow{2}{*}{\multicolumn{2}{|c|}{ Model }} & \multicolumn{2}{|c|}{$\begin{array}{c}\text { Unstandardized } \\
\text { Coefficients }\end{array}$} & \multirow{2}{*}{$\begin{array}{c}\text { Standardized } \\
\text { Coefficients } \\
\text { Beta }\end{array}$} & \multirow[t]{2}{*}{$t$} & \multirow[t]{2}{*}{ Sig. } & \multicolumn{2}{|c|}{ Collinearity Statistics } \\
\hline & & $\mathrm{B}$ & Std. Error & & & & Tolerance & VIF \\
\hline \multirow{4}{*}{1} & (Constant) & 3.663 & 1.103 & & 3.320 & .001 & & \\
\hline & Green_Strategy & .154 & .051 & .220 & 3.007 & .003 & .650 & 1.539 \\
\hline & Perceived_Quality & .332 & .096 & .342 & 3.451 & .001 & .355 & 2.813 \\
\hline & Brand Image & .223 & .075 & .319 & 2.961 & .004 & .300 & 3.335 \\
\hline
\end{tabular}

a. Dependent Variable: Purchase_Intention 
Based on this table, the regression equation can be prepared as follows:

$$
\mathrm{Y}=3.663+0.154 \mathrm{X}_{1}+0.332 \mathrm{X}_{2}+0.223 \mathrm{X}_{3}
$$

The regression equation are:

increases by one unit with the assumption of product quality and perceived quality of constant value.

- $\alpha=0.465$ means that consumer purchase interest is 3.663 units if the environmentally friendly strategy, perceived quality and brand image are zero.

- $\beta_{1}=0.154$ means that consumer buying interest will increase by 0.154 units if the environmentally friendly strategy increases by one unit with the assumption that the perceived quality and brand image are of fixed value.

- $\beta_{2}=0.332$ means that consumer buying interest will increase by 0.332 units if the perceived quality increases by one unit, assuming an environmentally friendly strategy and a fixed value brand image
- $\beta_{3}=0.223$ means that consumer buying interest will increase by 0.223 units if the brand image increases by one unit with the assumption of product quality and perceived quality of constant value.

\subsection{Results}

$\mathrm{H}_{1}$ : Based on Table 1.1 the sig value is $0.003: 2=0.0015(<$ 0.05 ), which means that $\mathrm{Ho}_{1}$ is rejected, it can be concluded that there is a positive effect between green labels on purchase intention of Plenty products in Jakarta.

$\mathrm{H}_{2}$ : Based on Table 1.1 the sig value is $0.001: 2=0,0005$ $(<0.05)$, which means that $\mathrm{Ho}_{2}$ is rejected, it can be concluded that there is a positive influence between perceived quality on purchase intention on Plenty products in Jakarta.

$\mathrm{H}_{3}$ : Based on Table 1.1 the sig value is 0.004: $2=0.002(<$ 0.05), which means that $\mathrm{Ho}_{3}$ is rejected, it can be concluded that there is a positive influence between perceived quality on purchase intention on Plenty products in Jakarta.

Table 2 F-Test

\begin{tabular}{|c|c|c|c|c|c|c|}
\hline \multicolumn{7}{|c|}{ ANOVA $^{*}$} \\
\hline & & Sum of Squares & Df & Mean Square & $\mathrm{F}$ & Sig. \\
\hline \multirow{3}{*}{1} & Regression & 481.400 & 3 & 160.467 & 57.146 & $.000^{\mathrm{b}}$ \\
\hline & Residual & 322.920 & 115 & 2.808 & & \\
\hline & Total & 804.319 & 118 & & & \\
\hline
\end{tabular}

a. Dependent Variable: Purchase_Intention

b. Predictors: (Constant), Brand_Image, Green_Strategy, Perceived_Quality

The results obtained, the Sig. Regression value of 0.000 is smaller or not greater than 0.05 , so that $\mathrm{H}_{0}$ is not rejected and it can be said that green label, perceived quality and brand image have a positive influence on purchase intention Plenty products in Jakarta.
To find out how much influence green label, perceived quality and brand image have on purchase intention, it can be seen through the Adjusted $\mathrm{R}^{2}$ value, the results of the Adjusted $\mathrm{R}^{2}$ test can be seen in the following table:

Table 3 Test of Goodness-of-Fit

Model Summary

\begin{tabular}{|l|r|r|r|r|r|}
\hline Model & R & R Square & \multicolumn{1}{|c|}{$\begin{array}{c}\text { Adjusted R } \\
\text { Square }\end{array}$} & \multicolumn{1}{c|}{$\begin{array}{c}\text { Std. Error of the } \\
\text { Estimate }\end{array}$} & Durbin-Watson \\
\hline 1 & $.774^{\mathrm{a}}$ & .599 & .588 & 1.67571 & 2.108 \\
\hline
\end{tabular}
a. Predictors: (Constant), Brand_Image, Green_Strategy, Perceived_Quality
b. Dependent Variable: Purchase Intention 
Based on Table 1.3, it can be seen that the results of the Adjusted $\mathrm{R}^{2}$ test are 0.588 , which means that $58.8 \%$ of the independent variables (green label, perceived quality, brand image) can explain the dependent variable (purchase intention), while the rest is influenced by other variables outside of this study.

\subsection{Conclusions}

The purpose of this study was to empirically test green label, perceived quality and brand image as predictors of purchase intention. Based on the results of discussion based on theory, relevant research, frameworks of thought, hypotheses and empirical testing related to all the hypotheses contained in this study, the following conclusions can be formulated:

1. Green label has a positive effect on purchase intention. So, the more often companies implement environmentally-friendly marketing strategies, the higher the consumer's buying interest to buy plenty of tissue.

2. Perceived quality has a positive effect on purchase intention. So, the better the consumer's perception of the quality of the product, the higher the consumer's buying interest in tissue plenty.

3. Brand image has a positive effect on purchase intention. So, the better Plenty's brand image, the higher consumer interest in buying Plenty tissue.

4. The variable ability of green label, perceived quality and brand image in explaining purchase intentions is $15.4 \%$, $33.2 \%$ and $22.3 \%$.

5. The variables that have the greatest influence are perceived quality, the two variables are brand image and the third is green label.

\section{REFERENCES}

[1] Hansen. (2013). Global forest watch. infografik. Available at https://infographicjournal.com/whatisglobal-forest-watch-and-how-do-youuse-it/ (Accesses: 2 January 2021)

[2] Chen, Y. S. (2012). The influences of green perceived quality and green brand awareness on green brand equity: the mediation effect of green perceived risk. Technology Management for Emerging Technologies Vol. 45 (1), 23-43.

[3] Wheelock, D., \& Wilson, P. (1995). explaining bank failures: deposit insurance, regulation, and efficiency. Journal of Money, Credit and Banking 77(4), 689-700.

[4] Magnusson, E., \& Cranfield, J. (2003). Canadian consumers $^{\text {ee }}$ willingness to pay for pesticide-free food products: An ordered probit analysis. International Food and Agribusiness Management Review, 6(4), 13-30.
[5] Hair, \& Joseph, F. (2006). Multivariate data analysis. New Jersey: Prentice Hall, Inc.

[6] Situmorang. (2010). Data penelitian; menggunakan program SPSS. Medan: USU Press. 